\title{
EXPLORING SOCIAL MEDIA AS AN ELECTRONIC TOOL IN THE UNIVERSITY CLASSROOM
}

\author{
Hal Records, Bryant University, Smithfield, RI \\ Janet Prichard, Bryant University, Smithfield, RI \\ Robert Behling, Arrowrock Technology, Chesapeake, VA
}

\begin{abstract}
Many of today's students live online, and social networking is an important part of their daily communications. This study investigates the use of social networking in the university classroom, surveying both students and faculty. A total of 182 students and 64 faculty from a northeast university provided usable responses. Findings indicate that social networking is not heavily used in the classroom, however it plays an important role in personal communications.
\end{abstract}

\section{INTRODUCTION}

We are experiencing a tsunami in higher education. The traditional university campus and curriculum is being flooded with new technologies, new techniques, and new populations. The student of the future may or may not ever set foot on a university campus, will experience technology enabled education unlike anything we have known, and will be organized and managed to expand access, increase performance, and save money. The classroom of the future will include face-to-face, online and hybrid learning, meeting the needs of both campus and distance learners (Parry, 2010).

A key element to all learning, the process of information discovery, is changing from a solitary activity to a communal activity, and how we exchange information is changing from a sharing activity (e-mail a friend) to sharing passively (uploading photos on facebook) and e-mailing notification that photos are available. What is happening is that we are separating notification from access ( Wharton, 2008).

Many of today's students live online. They are constantly texting, on their cell phone, and interacting through email and web browsers, so what better population to challenge with disruption of the status quo and a move into new technologies. Much of this is familiar territory for anyone teaching in the university environment, but there is one area that has seen a significant surge in the past several years: the growth and impact of social media and social networking sites. Gaining a better understanding of the use and impact of social media and social networking sites is an objective of this study. While perhaps only a small portion of the classroom of the future, indications are that social networking tools may be important to improve educational performance. Just the fact that there are well over 400 million Facebook accounts makes this an important tool for educators (Jardin, 2009).

Social media sites like Facebook, Linkedin and Twitter play a significant role in the way people connect online with others. Educators are finding uses for Twitter in the classroom (Lytle, 2011) and Linkedin is becoming a tool students can use to find jobs (Jacoway, 2011). In additional to being used recreationally, these social media sites are playing an ever increasing role in business and other professions. Uses include training, professional networking and knowledge sharing, and staying in touch with professional colleagues and potential employers. According to a 2009 Nielson report, users spent an average of six hours a day on social media sites, which is almost double what they found was spent in 2008 (Steffee, 2010). 
So, before continuing, it is important to define what we mean by social media. Wikipedia (2011) does a good job of providing a broad definition.

Condensed: A social network is a social structure made of individuals or organizations connected by one or more types of interdependency such as friendship, kinship, common interest, or relationships of beliefs. The shape of the social network and the strength of the ties determine the usefulness to individuals. More simply put; a social network is an online service for people who share an interest to collaborate and share information. Most social networks are web based, providing various ways for users to interact.

We should also note Metcalfe's Law - the inventor of Ethernet - which states the power of a network grows in proportion to the square of the number of nodes. As network popularity grows, so does the network value to the users (Jardin, 2009). We have seen a dramatic growth in social networking in recent years, and clearly it is a force to be reckoned with. This very rapid growth prompted the authors to investigate whether social networking is being used to support educational objectives in higher education. It is important to recognize that just utilizing technology to appear relevant does not equal actual learning (Young, 2010).

\section{LITERATURE SEARCH}

There is a danger that technologies are deployed and utilized because they are cool rather than for any specific learning goal (Young, 2010). Figure 1 provides a brief overview of some of the technology and activities that are or will be important in the $21^{\text {st }}$ century university learning environment. Social networking is only a small part of the global changes that are taking place, however the authors feel that it is an important to better understand these tools and to see how they fit into the environment of electronic tools currently available to teachers and learners.

\section{Figure 1: 21 ${ }^{\text {st }}$ Century Learning Environment}

Much of what is listed is not revolutionary nor leading edge, but it is important to recognize that the classroom of today and tomorrow will rely on more technology, new technologies, and resources such as social networking, course management, e-Tutorials and e-Books that have been made available because of evolving technology.

Participants University administrators (resources allocation), Faculty, students, support staff, publishers of electronic materials and others external to the classroom (guest speakers, experts), researchers

Electronic Communication Synchronous and asynchronous (voice, text, image, video)

Content/Resources Original, stored, e-books, tutorials, cases, PowerPoint, search engines, wikis, databases, live feeds

End User Communication Technologies Hardware: cell phones, mobile devices, laptops, PDA, notepad, desktop, cloud computing

Software: e-mail, instant messaging, classroom management (blackboard, desire2learn, banner), social networking, search engines, and application servers such as Citrix.

Delivery Mode Options Lecture, seminar, lab, recitation, discussion, web, online. Online and blended programs will play an increasingly important role in delivering higher education to students not physically present on campus.

When we think about social networking, FaceBook is often the first technology that comes to mind. They are reported to have almost 500 million users (Dybwad, 2010) and garner 68\% of all social networking advertising 
revenue (eMarketer, 2011). Mui and Whorisky (2010) recently reported that Facebook has passed Google as the most popular site on the internet, and it is estimated that 1/3 of all American internet users have a profile on a social networking site (Lenhart, 2009). Because young people increasingly rely on Facebook and Twitter to communicate in their personal lives, many educators and business leaders feel that we must bring similar tools to the workplace and classroom (Wharton, 2011). The age of social networking is here to stay, and it is important to be cognizant of the risks as well as the benefits of participating, especially given the addition of Skype with real time online video chat capabilities. (Guynn, 2011). About 2 of three business executives surveyed by Deloitte LLP stated that online social networking presents a range of challenges and opportunities for most organizations. They identified reputational risk with sites like Facebook and Twitter as a particular concern (AccountingWeb, 2009). Facebook is increasingly defining the parameters of online privacy through new features and ever-changing policies. Their approach is to act now and apologize later by repeatedly pushing the privacy envelope (Wharton, 2010).

Facebook has come under fire for recent policy changes that limit what users can keep private. The motivation for all social networking sites to restrict privacy is finding ways to turn the vast amount of captured data into ad revenue. It is estimated that the additional revenue gained from selling captured data could be in the billions of dollars (Vascellaro, 2010). The challenge with establishing and maintaining online privacy is that people care about privacy but have a difficult time in deciding where to draw the line. Also, there is currently no agreed upon legal definition of internet privacy (Wharton, 2010). Faculty account security is an issue when personal social networking accounts are used in class settings, and privacy continues to be an issue for both faculty and students (Young, 2010). Striking a balance between enriching the educational experience while limiting distractions, controlling access and manipulation of social networking accounts may be one of the more important challenges faculty will face during the next decade.

\section{RESEARCH QUESTIONS}

Because technology enabled education is becoming unlike anything we have known, research questions include: What are today's electronic tools? What are the categories by which these tools can be grouped? What is the proportion of social media used in the classroom in relation to other available electronic tools and in relation to personal use? What is the split between classroom/learning and personal use of these tools? Do students and faculty have similar or differing views on the use of these tools? What software and hardware tools are eclipsing others in the race for inclusion? What are the advantages/disadvantages of utilizing social media in the classroom? Do faculty and students view social media as a viable teaching/learning tool? Do faculty and/or students have security concerns with the use of social media for school sponsored classroom activities? What is the outlook for expansion of electronic tools in tomorrow's classroom?

\section{SURVEY DESIGN AND ADMINISTRATION}

Since surveys are well accepted as a means of data collection (Babbie, 2007), this study was based on survey data obtained from students and faculty at a Northeast University in May of 2011. Surveys were made available to faculty and students in either written or electronic format. Electronic responses were collected via SurveyMonkey, and written responses were posted into SurveyMonkey for tabulation. A total of 246 usable surveys, 64 from faculty and 182 from students were collected. Respondent demographics are male 59.8\% and female $40.2 \%$, College of Business 80\% and College of Arts \& Sciences 20\%, age 17-22 was 71.7\%, age 23-28 was 1.7\%, and greater than age 28 was $26.6 \%$.

Survey questions were selected by creating a list of electronic tools commonly used in the classroom, where classroom is loosely defined as the aggregate of in-class, out-of class, synchronous, and asynchronous software and hardware used in the teaching/learning process wherever it occurs in relation to any given course. 
Volume XII, No. 2, pp 171-180, 2011

\section{SURVEY RESULTS}

What are today's electronic classroom tools and what are the categories by which these tools can be grouped?

As shown by Exhibit 1 e-Classroom Tools, it was found that the 31 tools included the survey could be clustered into seven categories, and that Ning (an on-line site for people to create their own websites) shows very low utilization. Ning was dropped from the analysis leaving 30 specific tools. The categories into which these tools clustered are Academic Support, Electronic Books, Reference Resources, Desktop Applications, Communications, Social Networking, and Hardware Devices

\begin{tabular}{|l|}
\hline Academic Support \\
Blackboard \\
Banner \\
On-Line Tutorials (Connect, MyITLab, etc.) \\
On-Line Class Notes \\
Electronic Books \\
Electronic Books \\
Reference Resources \\
The Internet \\
Wikis (eg. Wikipedia) \\
Search (Google, Bing, Ask, etc.) \\
EBSCO Online \\
Desktop Applications \\
PowerPoint \\
Word \\
Excel Spreadsheet \\
Access Database \\
Communications \\
Text Messaging \\
Instant Messaging \\
e-Mail \\
Social Networking \\
Facebook \\
MySpace \\
Twitter \\
LinkedIn \\
Hardware Devices \\
Laptop Computer \\
Cell Phone \\
Blackberry \\
iPhone \\
iPod Touch \\
iPad \\
Android Device \\
Kindle \\
Nook \\
Classroom Clickers \\
\end{tabular}

Exhibit 1 e-Classroom Tools 
Volume XII, No. 2, pp 171-180, 2011

\begin{tabular}{|c|c|c|c|}
\hline \multicolumn{2}{|l|}{ Academic Usage Ranked by Category } & \multicolumn{2}{|l|}{ Personal Usage Ranked by Category } \\
\hline \multicolumn{2}{|l|}{ Academic Support } & \multicolumn{2}{|l|}{\begin{tabular}{|c|} 
Communication \\
\end{tabular}} \\
\hline Blackboard & $99.57 \%$ & Text Messaging & $91.71 \%$ \\
\hline Banner & $99.55 \%$ & Instant Messaging & $68.10 \%$ \\
\hline On-Line Tutorials (Connect, MylTLab, etc.) & $77.38 \%$ & e-Mail & $98.60 \%$ \\
\hline On-Line Class Notes & $74.44 \div$ & Average & $86.13 \%$ \\
\hline \multicolumn{2}{|l|}{ Average } & \multicolumn{2}{|l|}{$\begin{array}{r}\text { Reference Resources } \\
\end{array}$} \\
\hline \multicolumn{2}{|l|}{ Reference Resources } & The Internet & $100.00 \%$ \\
\hline The Internet & $98.16 \%$ & Wikis (eg. Wikipedia) & $78.26 \%$ \\
\hline Wikis (eg. Wikipedia) & $70.05 \%$ & Search (Google, Bing, Ask, etc.) & $99.54 \%$ \\
\hline Search (Google, Bing, Ask, etc.) & $97.70 \%$ & EBSCO Online & $23.66 \%$ \\
\hline EBSCO Online & $55.88 \%$ & Average & $75.36 \%$ \\
\hline \multicolumn{2}{|l|}{ Average } & \multicolumn{2}{|l|}{ Social Media } \\
\hline \multicolumn{2}{|l|}{ Communication } & Facebook & $82.73 \%$ \\
\hline Text Messaging & $51.83 \%$ & MySpace & $7.48 \%$ \\
\hline Instant Messaging & $35.16 \%$ & Twitter & $30.19 \%$ \\
\hline \multirow[t]{2}{*}{ e-Mail } & $98.63 \div$ & Linkedln & $35.75 \%$ \\
\hline & $61.88 \%$ & Average & $39.04 \%$ \\
\hline \multicolumn{2}{|l|}{ Electronic Books } & \multicolumn{2}{|l|}{\begin{tabular}{|r|} 
Electronic Books \\
\end{tabular}} \\
\hline Electronic Books & $57.99 \%$ & Electronic Books & $31.90 \%$ \\
\hline \multicolumn{2}{|l|}{ Social Media } & \multicolumn{2}{|l|}{ Academic Support } \\
\hline Facebook & $41.58 \%$ & Blackboard & $33.54 \%$ \\
\hline MySpace & $2.04 \%$ & Banner & $45.40 \%$ \\
\hline Twitter & $11.98 \%$ & On-Line Tutorials (Connect, MylTLab, etc.) & $18.71 \%$ \\
\hline \multirow[t]{2}{*}{ Linkedln } & $31.63 \%$ & On-Line Class Notes & $19.73 \%$ \\
\hline & $21.81 \%$ & Average & $29.34 \%$ \\
\hline \multicolumn{2}{|l|}{ Desktop Applications } & \multicolumn{2}{|l|}{$\begin{array}{r}\text { Desktop Applications } \\
\end{array}$} \\
\hline PowerPoint & $96.89 \%$ & PowerPoint & $66.06 \%$ \\
\hline Word & $98.64 \%$ & Word & $93.79 \%$ \\
\hline Excel Spreadsheet & $97.33 \%$ & Excel Spreadsheet & $76.47 \%$ \\
\hline Access Database & $62.16 \div$ & Access Database & $25.16 \%$ \\
\hline Average & $88.76 \%$ & Average & $65.37 \%$ \\
\hline \multicolumn{2}{|l|}{ Hardware } & \multicolumn{2}{|l|}{ Hardware } \\
\hline Laptop Computer & $96.30 \%$ & Laptop Computer & $94.76 \%$ \\
\hline Cell Phone & $71.88 \%$ & Cell Phone & $95.89 \%$ \\
\hline Blackberry & $22.92 \%$ & Blackberry & $29.52 \%$ \\
\hline iPhone & $18.23 \div$ & iPhone & $22.54 \%$ \\
\hline iPod Touch & $12.97 \%$ & iPod Touch & $36.62 \%$ \\
\hline iPad & $9.74 \%$ & iPad & $12.32 \%$ \\
\hline Android Device & $15.54 \div$ & Android Device & $22.97 \%$ \\
\hline Kindle & $4.17 \%$ & Kindle & $9.31 \%$ \\
\hline Nook & $2.03 \%$ & Nook & $5.80 \%$ \\
\hline Classroom Clickers & $27.62 \%$ & Classroom Clickers & $3.19 \%$ \\
\hline Average & $28.14 \%$ & Average & $33.29 \%$ \\
\hline
\end{tabular}

Exhibit 2 - Relative Use of e-Classroom Tools by Category for Academic and Personal Us 
Volume XII, No. 2, pp 171-180, 2011

What is the proportion of social media used in the classroom in relation to other available electronic tools, and in relation to personal use?

For purposes of this analysis Hardware and Desktop Applications are viewed as foundations to an e-Classroom and are included to show their necessary presence, but not included in the relative use comparison.

The survey provided respondents with three choices by which they could indicate their level of classroom use and the same three levels by which they could report their personal use, these were "Never", "Occasionally", and "Frequently". Examination of survey data indicated that "Occasionally" and "Frequently" should be combined to provide a more accurate picture of classroom versus personal use. An example of this is Banner (a common course scheduling, registration and grading tool) where $45.5 \%$ of respondents reported occasional use and $50.2 \%$ frequent use. The fact that $95.7 \%$ of respondents use Banner indicates that it is indeed an essential tool.

Exhibit 2 helps to answer the question of social media use in the e-Classroom versus use for personal purposes. Respondent use of the social networking bundle in the survey averages approximately $22 \%$ in the classroom and 39\% for personal, with Facebook being far and away the most frequently used. Exhibit 2 also helps to answer the question of social media's use in the e-Classroom versus other electronic tools. The ranking from highest use to lowest is Academic Support, Reference Resources, Communication, Electronic Books, and Social Media. (Remember Desktop Applications are not included in this list.) In the classroom, Social Media is dead last. The ranking for personal use is Communication, Reference Resources (surprisingly), Social Media, Electronic Books, and last Academic Support (not surprisingly). Having learned how categories of e-tools stack up against each other, the next step is to see how individual tools fare.

\section{Do students and faculty have similar or differing views on the use of these tools?}

Exhibit 3 shows that faculty and student use are in many ways similar. For example nine out of the top ten tools for academic use are the same for both faculty and students. The mismatch tools are EBSCO on-line (a research tool) used by faculty and On-Line Tutorials used by students. We also see that relative usage is similar between faculty and students. When looking at personal use, eight out of the top ten tools are the same for faculty and students. 
Volume XII, No. 2, pp 171-180, 2011

\begin{tabular}{|ll|}
\hline \multicolumn{2}{|c|}{ Top 10 Academic (Faculty) } \\
Blackboard & $98.33 \%$ \\
Banner & $98.31 \%$ \\
Word & $98.28 \%$ \\
e-Mail & $98.28 \%$ \\
The Internet & $93.22 \%$ \\
PowerPoint & $91.67 \%$ \\
Search & $91.53 \%$ \\
Excel Spreadsheet & $91.23 \%$ \\
Laptop Computer & $85.96 \%$ \\
EBSCO Online & $57.14 \%$ \\
\hline
\end{tabular}

\begin{tabular}{|lr|}
\hline \multicolumn{2}{|c|}{ Top 10 Academic (Student) } \\
Blackboard & $100.00 \%$ \\
Banner & $100.00 \%$ \\
The Internet & $100.00 \%$ \\
Search & $100.00 \%$ \\
Laptop Computer & $100.00 \%$ \\
Excel Spreadsheet & $99.40 \%$ \\
Word & $98.78 \%$ \\
PowerPoint & $98.77 \%$ \\
e-Mail & $98.74 \%$ \\
On-Line Tutorial & $88.82 \%$ \\
\hline
\end{tabular}

\begin{tabular}{|lr|}
\hline \multicolumn{2}{|c|}{ Top 10 Personal (Faculty) } \\
The Internet & $100.00 \%$ \\
Search & $100.00 \%$ \\
e-Mail & $100.00 \%$ \\
Cell Phone & $94.44 \%$ \\
Word & $93.88 \%$ \\
Laptop Computer & $84.31 \%$ \\
Excel Spreadsheet & $80.43 \%$ \\
Text Messaging & $75.00 \%$ \\
Wikis (eg. Wikipedia) & $70.91 \%$ \\
PowerPoint & $53.33 \%$ \\
\hline
\end{tabular}

\begin{tabular}{|lr|}
\hline \multicolumn{2}{|c|}{ Top 10 Personal (Student) } \\
The Internet & $100.00 \%$ \\
Search & $99.38 \%$ \\
e-Mail & $98.13 \%$ \\
Laptop Computer & $98.09 \%$ \\
Cell Phone & $96.93 \%$ \\
Text Messaging & $96.93 \%$ \\
Facebook & $94.44 \%$ \\
Word & $93.70 \%$ \\
Wikis (eg. Wikipedia) & $80.67 \%$ \\
Instant Messaging & $79.11 \%$ \\
\hline
\end{tabular}

\section{Exhibit 3 Comparison of Top 10 e-Tool Use by Faculty and Students}

For personal, the mismatch is high faculty use of Excel and PowerPoint versus high student use of Facebook and Instant Messaging. Here again use rates are very similar between faculty and students for each of the tools, except Facebook that has a whopping $94 \%$ rate.

\section{What software and hardware tools are eclipsing others in the race for inclusion?}

Exhibit 3 shows the top 10 as of 2011, but further study of Exhibit 2 shows a stronger than anticipated 58\% presence for electronic books in the classroom. This may be a result of efforts to reduce the exorbitant cost of traditional (someday to be legacy) text books and may be a precursor to an increase in personal e-Book

use which is presently $32 \%$. It also appears that computer or mobile devices are far and away the vehicle of choice for delivery of book content as opposed to dedicated devices such as Nook and Kindle. Text messaging appears to be eclipsing instant messaging, wikis maintain a strong presence as do search engines, and Facebook dominates Social Networking.

\section{What are the advantages/disadvantages of utilizing social media in the classroom?}

Respondents were asked to enter their comments on the advantages and then on the disadvantages of Social Networking in the classroom and approximately $65 \%$ of the 246 respondents did so. Advantages clustered around Connectivity, Communication, Participation, Group Work, Real Time, Use Anywhere, Real World Examples, For people who are uncomfortable speaking in class, Being able to participate in class when sick, and one comment "Ability to cheat on tests".

Disadvantages clustered heavily around Distraction and Disruption (89\% of students and $45 \%$ of faculty). Comments include It gets you sucked in and you end up looking at pictures instead of doing work, People often pay 
Volume XII, No. 2, pp 171-180, 2011

more attention to the computer than to what is going on in the classroom, and It is easy to get distracted and browse non academic information.

\section{Do faculty and/or students have security concerns with the use of social media for school sponsored classroom activities and do they view Social Media as a viable teaching/learning tool?}

Approximately $96 \%$ of respondents indicated that Social Media is never or occasionally appropriate for classroom learning and $95 \%$ indicated that it was never or occasionally an effective learning tool.

\section{Do faculty and/or students have security concerns with the use of social media for school sponsored classroom activities?}

Approximately $25 \%$ of respondents indicate that Social Media is never a security risk, $57 \%$ occasionally a security risk, and $18 \%$ frequently a security risk.

\section{What is the outlook for expansion of electronic tools in tomorrow's classroom?}

Respondents were asked if they are using more electronic classroom tools today than one year ago and if they anticipate using more next year than this. Approximately $82 \%$ indicated that they are using more than last year, and approximately $76 \%$ anticipate they will be using even more next year.

\section{DISCUSSION OF THE RESULTS}

Our research findings support the notion that the process of information discovery, is changing from a solitary activity to a more communal activity and that this migration is supported by electronic tools in support of both team and individual academic efforts. How we exchange information is changing from a sharing activity (e-mail a friend) to sharing passively (uploading photos on Facebook) and both synchronous and asynchronous media are robust ingredients of the electronic classroom. Educators have identified many specific ways to use Social Media in the classroom. (Online Universities, 2010). Students are constantly texting, on their cell phone, and interacting through e-mail and web browsers. Laptop computers followed by cell phones, Blackberry devices, and for students IPod Touch and Android devices top the list of hardware used. One somewhat surprising and perhaps fortuitous finding is that e-Books are used for academic purposes occasionally and frequently 55.7\% of the time and On-Line Tutorials are used $75 \%$ of the time. Comparing this use against the very low (1\% to 5\%) use of book readers Kindle and Nook, argues that both faculty and students rely on some combination of laptops and mobile devices for display of electronic book content.

As previously stated much of this is familiar territory for anyone teaching in the university environment and it may be a precursor of what to expect in the workplace moving forward. Social media sites like Facebook, Linkedin and Twitter play a significant role in the way people connect online with others and Facebook is the dominant player with a reported $65 \%$ use by students. Even with that level of personal use, students and faculty as a whole do not see Social Media as a highly useful classroom tool, hence our research supports Young's warning that that there exists a danger that these technologies may be deployed and utilized because they are cool rather than for any specific learning goal.

\section{CONCLUSIONS}

Social networking is not big and has limitations in the classroom. It is viewed as a distraction by both faculty and students, but is dominant in personal communication for students. Students and faculty largely agree on the 10 or 11 most useful tools of an electronic classroom. These are Blackboard, Banner, Word, e-Mail, The Internet, 
Volume XII, No. 2, pp 171-180, 2011

PowerPoint, Search Engines, Excel, Laptop Computers, EBSCO Online, and On-Line Tutorials. The top ten electronic tools for personal use are very similar and include Facebook with $94 \%$ use, Wikis and Instant Messaging. Laptop and mobile device e-Book use is stronger than expected in the classroom and is likely to increase at least in part driven by the increased availability of electronic content and the rising costs of traditional textbooks.

\section{FUTURE RESEARCH}

Future research to learn how use of these tools evolves over time, how faculty elect to integrate them into classroom experience, how they impact learning outcomes and how they impact the cost of education can assist educators and administrators with the task of embracing and expanding the electronic classroom. Such research can also help to define a realistic proportion by which to blend electronic and traditional education.

\section{REFERENCES}

1. . (2010) “Act Now, Apologize Later: Will Users ‘Friend' Facebook’s Latest Invasion of Privacy?,"

Knowledge at Wharton, May 12, retrieved from:

Http://Knowledgewharton.upenn.edu/article.cfm?articleid=2482.

2. . (2011) "Is Business-Centric Social Networking a Revolution - or a Ruse," Knowledge at Wharton, March 02, retrieved from: Http://Knowledgewharton.upenn.edu/article.cfm?articleid=2725.

$3 . \quad$. (2008) "Not a Site But a Concept: Tapping the Power of Social Networking," Knowledge at Wharton, July 9, retrieved from: Http://Knowledgewharton.upenn.edu/article.cfm?articleid=2009.

4. _. (2009) "Social Networking Presents Serious Concern to Business Owners," AccountingWeb, retrieved from:www.accountingweb.com/print/node/147882.

5. _ (2011) "Social Network,"Wikipedia, retrieved from: http://en.wikipedia.org/wiki/social_network.

6. _ (2011) “Worldwide Social Network Ad Spending," eMarketer, February 25, retrieved from: www.webstrategies.com/blog.

7. Babbie, E. (2007) The Practice of Social Research, $11^{\text {th }}$ Ed, Thompson, Belmont, CA.

8. Dybwad, B. (2010) "Facebook Passes the 400 Million User Mark, Mashable, February 4, retrieved from: http://mashable.com/2010/02/04/facebook-400-million/.

9. Jardin, X. (2009) “Online Social Networks Go to Work,” MSNBC.com, retrieved from: http://www.msnbc.msn.com/id/5488683/.

10. Lenhart, A. (2009) "Pew Internet Project Data Memo," Pew Internet and American Life Project, Washington, DC.

11. Mui, Y. and P. Whoriskey. (2010) "Facebook Passes Google as Most Popular Site on the Internet, Two Measures Show," Washington Post, December 31, retrieved from: www.pewinternet.com/mediamentions/2010.

12. Parry, M. (2010) “Tomorrow's College," The Chronicle of Higher Education, October 31, retrieved from: http://Chronicle.com/article/tomorrow-college/12.

13. Steffee, S. (2010) “Leveraging Social Media," Internal Auditor, February, retrieved from: www.theiia.org/intauditor/feature-articles/2010/february/leveraging-social-media.

14. Vascellaro, J. (2010) “Facebook Grapples with Privacy Issues," The Wall Street Journal, May 19, retrieved from: http://online.wsj.com/article/SB10001424052748704912004575252723109845974.htm.

15. Young, J. (2010) "How Social Networking Helps Teaching (and Worries Some Professors)," The Chronicle of Higher Education, July 22, retrieved from: http://chronicle.com/article/how-social-networking-helps/123654.

16. _. (2010) "100 Inspiring Ways to Use Social Media In the Classroom," Online Universities, May 4, retrieved from: http://www.onlineuniversities.com/blog/2010/05/100-inspiring-ways-to-use-social-media-inthe-classroom/. 
Volume XII, No. 2, pp 171-180, 2011

17. Guynn, J. (2011) "Facebook adds video-calling Skype — at no charge," StarTribune, retrieved from: http://www.startribune.com/business/125117979.html.

18. Lytle, R. (2011) "5 Unique Uses of Twitter in the Classroom," US News and World Report, May 14, retrieved from: http://www.usnews.com/education/best-colleges/articles/2011/05/24/5-unique-uses-of-twitter-in-theclassroom.

19. Jacoway, K, (2011) “Are You Visible In Your Job Search?” Classroom to Cubicle Magazine, February 22, retrieved from: http://classroomtocubicle.com/finding-landing/social-media/two-brand-new-features-onlinkedin/. 